\title{
COST OF MINING COAL AS AN ELEMENT OF MULTI-CRITERIA ASSESSMENT USING THE DEVELOPMENT MEASURE - A CASE STUDY
}

\author{
Aleksandra SULIK-GÓRECKA \\ University of Economics in Katowice \\ Zygmunt KORBAN \\ Silesian University of Technology
}

\begin{abstract}
:
The paper presents the possibilities of applying one of the multi-criteria assessment methods (the development measure method) in the processes of multi-variant design of technical and organizational solutions on the example of selecting equipment for a newly designed mine working in a hard coal mine. Using the case study, the authors proposed an alternative solution for decision-making problems in mining companies in relation to solutions based solely on unit costs of coal mining. The case study is preceded by the presentation of general principles regarding cost accounting in mining companies as well as the use of multi-criteria assessments.
\end{abstract}

Key words: cost accounting, coal, multi-criteria assessment, decision-making process

\section{INTRODUCTION}

The competitiveness of every business entity, including plants (companies) in the hard coal mining industry is often identified with efficiency - it is the sale price and the level of coal mining costs that determine the "attractiveness" of the product. In case of the sale price, it is difficult to talk about its free development (it is a derivative of prices on international markets), while in case of mining costs, although they can be shaped, but one should be aware that in the current situation of hard coal mining in Poland the possibilities to reduce production costs are quite limited. This is mainly due to the conditions under which mining works are carried out (location of mine workings, level of natural hazards, etc.) and the amount of resources held [4, 7]. In a market economy, minimizing own costs is a necessity which means that the decisionmaking process is dominated by solutions where we deal with the highest positive unit accumulation value (the difference between the average price and the level of own costs) [8]. However, it should be noted that in accordance with the principles of mining production ("the principle of economization" and "the principle of optimal result"), the financial result cannot be the only criterion for assessment, and thus it cannot be achieved, for example, at the expense of quality of working conditions.

The aim of the paper is to present the possibility of applying one of the multi-criteria assessment methods (the development measure method) in the processes of multi- variant design of technical and organizational solutions on the example of selecting equipment for the newly designed mine workings in a hard coal mine. As part of the multi-criteria assessment presented above, unit costs of coal mining are only one element of the decision-making process. The paper uses the method of the analysis of the results of published studies concerning the cost accounting in mining companies and the principles of building multi-criteria analyzes. A case study is also presented and discussed.

\section{GENERAL PRINCIPLES OF COST ACCOUNTING IN MINING COMPANIES}

Cost measurement in modern enterprises is an important factor affecting the value of company's financial result. An equally important area of cost accounting are decisionmaking cost accounts, which are not systematic, but concern specific decisions made under specific management conditions. In decision-making tasks limited to minimizing costs, costs can appear as a function of the goal. In other more complex situations, costs can be quantities that occur under limiting conditions for decision-making models [11]. For production engineering cost calculations are one of the elements of planning, direction and coordination of all manufacturing processes. The remaining elements in the decision-making processes are the issue of cost drivers, time involved, existing production resources, quality, and human resources [9]. 
The methodology for the valuation of coal mining costs is a significant practical and scientific problem widely analyzed in countries obtaining this resource $[17,18]$ Mining companies, like all other entities, run a systematic cost account in accordance with the Polish Act on Accounting (AoA) or International Accounting and Financial Reporting Standards (IAS/IFRS), and the cost of manufacturing is one of the basic parameters of accounting valuation [19].

According to art. $28 \mathrm{AoA}$, costs directly related to a given product and a justified part of costs indirectly related to the production of this product must be added to costs of production. Direct costs include the value of used direct materials, mining and processing costs directly related to production and other costs incurred in connection with bringing the product to the form and location in which it is located on the valuation day. A part of indirect costs is variable indirect production costs and that part of fixed, indirect production costs that corresponds to the level of these costs in the normal use of production capacity. The average level of production for a given number of periods or seasons, taking into account planned repairs, is considered as the normal level of utilization of production capacity [20].

Similar regulations regarding the valuation of production costs of products are included in IAS 2 Inventories. Variable indirect production costs, according to IAS 2, point 12, change directly or almost directly with the change in production volume, for example, indirect material and labor costs. Fixed indirect production costs, according to IAS 2, point 12 , remain at a relatively unchanged level, regardless of the production volume. These are, for example, the costs of depreciation and maintenance of buildings and factory equipment as well as the costs of management and administration [6]. According to IAS 2, in order to allocate fixed indirect production costs to products, as in AoA, the normal production volume is assumed. Normal production capacity, which is expected to be obtained during several periods or seasons, in typical circumstances, is determined on an average level, taking into account the loss of production capacity resulting from planned maintenance, and unallocated indirect production costs are treated as costs in period [6, 20].

The AoA provides that in cases justified by the necessary long-term preparation of goods or product for sale or a long production period, the purchase price or production cost may be increased by the costs of servicing liabilities incurred to finance the supply of goods or products during their preparation for sale or manufacture and related exchange differences, less related revenue [20]. Also under the IAS/IFRS provisions, under some circumstances, it is possible to classify the borrowing costs as production costs in accordance with IAS 23 as costs of external financing [6].

In addition, mining companies are subject to legal regulations in force in the European Union, resulting from, for example, Regulation of EC Council No. 1407/2002 of 23 July 2002 on state aid to the coal industry. Pursuant to the Regulation, production costs of coal, including, apart from operation, also operations connected with coal processing and transport to the collection point, as well as depreciation and interest on borrowed funds financing production should be considered as current coal production costs. It is recommended that these costs include ordinary depreciation and interest on borrowed funds. The costs of current coal production cannot include, for example, costs incurred for research and development, costs of environmental protection or training costs [3].

The main difference in the cost scheme resulting from the Regulation in relation to the provisions of the Accounting Act is the inclusion in the costs of coal production of the costs of employment restructuring, costs of liquidation of mining damage. According to the Accounting Act, these are other operating costs. According to the Regulation, the costs of financing should be included in the costs of coal production, and according to the Accounting Act, it is a solution provided for in specific situations, apart from which these costs are shown in the financial activity. The unit result on the sale of coal as a difference between the price and the cost of production is often perceived as a measure of pro-efficiency measures taken by the management of mines. This approach may encourage management not to show all expenditures on coal production in normal operations, due to their impact on the unit cost of coal mining. It should be noted, however, that the unit cost of coal mining cannot be the only decision criterion because quality parameters are also important. Unfortunately, it is not always possible to translate the quality parameters into a price, hence the profitability analysis is necessary, allowing to assess the possibility of a maximum, technically justified level of mining at economically optimal quality parameters [1].

An example of a qualitative factor analysis of coal mining was presented by W. Naworyta who, apart from the costs of mining and processing of minerals, took into account the variability parameters of the deposit, such as calorific value, sulfur content, non-flammable content and sand [12].

\section{ADOPTION OF MULTI-CRITERIA ASSESSMENT IN THE DE- CISION-MAKING PROCESS}

In a classical decision theory, the decision-making process is a group of logically-related (computational) operations that lead to solving the decision problem by selecting one of possible (according to a decision-maker - the best one) options of action. The choice of equipment and method of conducting works (selection of technical and organizational system) in a hard coal mine is a special case of the decision-making process, which in its general meaning comes down to:

- setting goals to be achieved,

- developing a set of alternative ways to achieve these goals,

- defining assessment (selection) criteria,

- choosing an option of action.

In the decision-making process, we deal with single- or multi-criteria tasks, while in most cases the choice of a solution is usually either to determine the best decision (usually by subjective judgment) or to divide decisions into equally good (satisfactory) decision classes ). In the latter case, therefore, we have to deal with the ordering 
of a set of decisions or with the allocation of decisions to predefined categories (so-called: sorting of elements of a set).

In the case of solving multi-criteria tasks (tasks of this type dominate in practice), one of the most frequently used methods is the development measure method. It is based on the determination of average distances between normalized values of attributes (variables) describing objects, and the values of attributes (variables) of the adopted standard solution (a hypothetical, ideal solution). The calculation procedure requires the determination of both the values of the characteristics of the objects being assessed and the characteristics of the accepted ideal pattern. These characteristics are subject to standardization, which allows them to be made comparable (unification). For the purposes of normalization, it is necessary to determine the nature of the characteristics (variables): stimulant, destimulant and nominant (in case of the latter, ranges should be indicated in which they act as stimulants, and in which as destimulants).

The benchmark solution is defined as the abstract $P_{o}$ point with coordinates $\left\{x_{o 1}, x_{o 2}, \ldots x_{o l}\right\}$ meeting the following conditions $[10,14,15,16]$ :

$$
x_{o j}=\max x_{i j} \quad \text { when } j \in S
$$

where:

$S$ - set of stimulant.

where:

$$
x_{o j}=\min x_{i j} \quad \text { when } j \in D
$$

$D$ - set of destimulant.

The distance between individual objects (points) $P_{i}$ and $P_{o}$ is defined as the weighted Euclidean distance [10, 14, 15, 16]:

$$
C_{i o}=\sqrt{\sum_{j=1}^{n} \alpha_{j}\left(x_{i j}^{\prime}-x_{o j}^{\prime}\right)^{2}}
$$

where:

$x_{i j}^{\prime}$ - normalized coordinates of $P_{i}$ point

$\alpha_{j}-$ significance (rank) of $j$-th characteristics (values determined, e.g. based on a survey of expert opinions).

In the development measure method, the decision is made on the basis of the designated value $m_{i}$ :

$$
m_{i}=1-\frac{c_{i o}}{c_{\text {io } \max }}
$$

where:

$m_{i} \in \leq 0 ; 1 \geq$, when the more the value $m_{i}$. approaches the value of 1 , the more the object meets the expectations of the decision maker (it is more developed).

\section{APPLICATION OF THE DEVELOPMENT MEASURE IN THE PROCESS OF MULTIVARIANT DESIGN OF TECHNICAL AND ORGANIZATIONAL SOLUTIONS IN AN EXAMPLARY HARD COAL MINE - A CASE STUDY}

The subject of the assessment were four mechanized longwall miners (longwall miners no. I-IV), which allow for mining a coal bed with a thickness of 1.9-3.2 $\mathrm{m}$ and a retention angle of $2-13^{\circ}$. In the roof of the bed, there are layers of argillaceous schist with average bedding and sandy schist, about 9.0 m thick, which makes it possible to conduct a mine with an automatic roof collapse. The planned length of the mining heading ranges from $235 \mathrm{~m}$ to $275 \mathrm{~m}$ ("closing wall" (ending operation) in the extracted batch p. 621).

Based on the opinion survey of experts (high-level supervision of energy-mechanical and mining departments, employees of the production and investment implementation department), a seven-element set of features being the subject of multi-criteria assessment was defined:

- financial outlay,

- daily mining,

- unit cost of mining,

- safety,

- warranty and service terms and conditions,

- post-warranty terms and conditions,

availability of spare parts.

The output data for calculations are presented in Table 1.

Table 1

Comparison of output data for calculations

\begin{tabular}{llcccc}
\hline No. $\begin{array}{c}\text { Characteristics } \\
\text { (assessment } \\
\text { parameter) }\end{array}$ & Unit & I & II & III & IV \\
\hline 1. Financial outlay & {$[\mathrm{kPLN}]$} & 68750 & 54254 & 48000 & 59345 \\
2. Daily mining & {$[\mathrm{Mg}]$} & 14000 & 12000 & 9500 & 10000 \\
3. Unit cost of mining & $\begin{array}{l}{[\mathrm{PLN} /} \\
\mathrm{Mg}]\end{array}$ & 190 & 182 & 217 & 189 \\
4. Safety & point & 8 & 9 & 8 & 8 \\
$\begin{array}{l}\text { Warranty and service } \\
\text { terms and conditions }\end{array}$ & point & 7 & 6 & 8 & 7 \\
$\begin{array}{l}\text { Post-warranty terms } \\
\text { and conditions }\end{array}$ & point & 7 & 6 & 7 & 6 \\
$\begin{array}{l}\text { Availability of spare } \\
\text { parts }\end{array}$ & point & 8 & 8 & 5 & 6 \\
\hline
\end{tabular}

The volume of financial outlay concerns the purchase of mechanized complexes (machines and devices) and it consists of the values of commercial offers from producers, while the value of daily mining corresponds to catalog values. The unit mining costs have been determined based on the formula [14]:

$$
\begin{gathered}
k_{j}=\frac{l_{z} \times o b s \times t_{z b r} \times p l_{s r}}{l d_{m-c} \times Z_{s}}+\frac{a \times t_{z b r}}{l d_{r o k} \times Z_{s}}+\frac{a}{l d_{r o k} \times W_{d} \times \eta}+\frac{S_{k r}}{l d_{m-c} \times W_{d} \times \eta}+ \\
+\frac{P_{m} \times P P_{m} \times C_{j k w h}}{W_{d} \times \eta}+\frac{S_{z m}}{l d_{m-c} \times W_{d} \times \eta}
\end{gathered}
$$

where:

$I_{z}$ - daily number of shifts,

obs - manning (on all shifts during the day)

$t_{z b r}$ - reinforcement time,

$p I_{s r}$ - average monthly pay,

$I d_{m-c}-$ number of working days per month,

$Z_{s}$ - longwall resources,

$a$-depreciation,

Id $d_{\text {rok }}$ - number of working days per year,

$W_{d}$ - daily mining,

$\eta$ - waste coefficient,

$S_{k r}$ - total labor cost per month,

$P_{m}$ - power consumption,

$P P_{m}$ - conversion rate of power consumption,

$C_{j k w h}$ - electricity price,

$S_{z m}$ - total material consumption. 
The values of characteristics no. 4-7 (qualitative assessment parameters) were adopted on a scale of 1 to 10 ( 1 - the lowest rating possible, 10 - maximum rating) based on the results of the community interview carried out in the group of high-level supervisors of energy-mechanical and mining departments, employees of the production preparation and investment department of the mine.

Based on the results of the survey, the weights (significance) of individual criteria were determined (Table 2).

Table 2

Adapted significance of criteria in assessment variants

\begin{tabular}{llc}
\hline No. & \multicolumn{1}{c}{$\begin{array}{c}\text { Characteristics } \\
\text { (assessment parameter) }\end{array}$} & $\begin{array}{c}\text { Significance of characteristics } \\
\text { (assessment parameter) }\end{array}$ \\
\hline 1. & Financial outlay & 0.9 \\
2. & Daily mining & 0.9 \\
3. & Unit cost of mining & 0.9 \\
4. & Safety & 0.9 \\
5. & Warranty and service & 0.8 \\
& terms and conditions \\
6. $\quad$ Post-warranty terms and & 0.5 \\
& conditions & 0.8 \\
\hline
\end{tabular}

In the process of normalizing variables (the procedure allowing for their mutual comparison and further analysis), the method of zero unitarization was used $[2,5,13]$ :

$$
\begin{aligned}
x_{i j}^{\prime}=\frac{x_{i j}-\min _{i} x_{i j}}{\max _{i} x_{i j}-\min _{i} x_{i j}} & X_{j} \in S \\
x_{i j}^{\prime}=\frac{\max _{i} x_{i j}-x_{i j}}{\max _{i} x_{i j}-\min _{i} x_{i j}} & X_{j} \in D
\end{aligned}
$$

The comparison of characteristics (assessment parameters) in the form of normalized values is presented in Table 3 .

Table 3

Comparison of the output data in the form of normalized values

\begin{tabular}{llcccc}
\hline \multirow{2}{*}{ No. } & Characteristics & \multicolumn{4}{c}{ Equipment variant } \\
& (assessment parameter) & I & II & III & IV \\
\hline 1. & Financial outlay & 0.000 & 0.699 & 1.000 & 0.453 \\
2. & Daily mining & 1.000 & 0.556 & 0.000 & 0.111 \\
3. & Unit cost of mining & 0.771 & 1.000 & 0.000 & 0.800 \\
4. & Safety & 0.000 & 1.000 & 0.000 & 0.000 \\
5. $\quad$ Warranty and service terms & & & & \\
& and conditions & 0.500 & 0.000 & 1.000 & 0.500 \\
6. $\quad \begin{array}{l}\text { Post-warranty terms and } \\
\text { 7. }\end{array}$ & 1.000 & 0.000 & 1.000 & 0.000 \\
7. & Availability of spare parts & 1.000 & 1.000 & 0.000 & 0.333 \\
\hline
\end{tabular}

The table of values of the development measure is presented in Table 4.

Table 4 Comparison of mi value

Equipment variant

\begin{tabular}{ccccc} 
& I & II & III & IV \\
\hline mi & 0.235 & 0.332 & 0.000 & 0.079 \\
\hline
\end{tabular}

Based on the calculations made, it can be concluded that in the framework of the multi-criteria assessment, option II should be considered as the most advantageous one, where the value of $m i$ development measure equals to 0.332. Tree times this variant came out as the first one, in the single-criterion assessment (unit cost (PLN 182), safety (9 points) and availability of spare parts ( 8 points), ex aequo with option I and twice the last rating (assessment of warranty and service terms and conditions (6 points), assessment of post-warranty terms and conditions (6 points) ex aequo with option IV) Second in line as part of the multi-criteria assessment - option I ( $\mathrm{mi}=$ 0.235 ) - also three times, in the single-criterion assessment, took the first rating (daily mining (14000 T), postwarranty terms and conditions (7 points) ex aequo with option III, availability of spare parts (8 points) ex aequo with option II) and also twice last ratings (financial outlay (PLN 68750 000) and assessment of safety conditions (8) ex aequo with options III and IV).

\section{DISCUSSION}

Cost measurement in mining companies is an extremely important factor affecting the financial result, due to the high share of fixed costs in the overall cost structure. Mining companies are entities subject to the provisions of the Accounting Act or IFRS also in the scope of cost records and their presentation related to coal mining. The economic conditions of mines are not the only ones that affect their survival in the long run. Equally important, for example, are the safety and comfort of mine underground crews who, in conditions of strong competition, increasingly affect the position of the company on the market and its image. In the situation of equal treatment of the production sphere with the issues of quality management, health and safety management or environmental management, there is a growing lack of approval for work in conditions that endanger the health and life of the employee, and the financial result, though very important, can only be one of criteria taken into account in the broadly understood decision-making process.

According to the above-mentioned approach of other authors $[1,9,11,12]$, the decision-making processes concerning the possibility of coal mining should take into account various other factors besides financial ones, including also qualitative parameters. In these processes, classical decision theory instruments can be used, in which the decision-making process means a group of logically related steps of thinking (computational operations) leading to the solution of a decision problem by selecting one of the possible (according to a decision maker - the best one) options of action. In the presented example of the selection of technical and organizational system, the objectives to be achieved were set, a set of alternative ways to achieve these objectives was elaborated, the criterion of the assessment was determined and the choice of the action variant was made. Among the parameters assessed, the financial outlay and unit cost of mining are partial elements of the assessment, within which also daily mining, safety, warranty conditions and servicing of 
machines, post-warranty terms and conditions and the availability of spare parts were taken into account.

The development measure method was used to select the best variant, which is based on the determination of average distances between normalized values of characteristics describing objects and the values of the characteristics of the adopted solution (the so-called standard solution). Selected option II was also the best in the single-criterion assessment in terms of such factors as: unit cost, safety and availability of parts. The applied solution can be modified and adapted to the specifics of decision-making problems, especially in the context of the selection of assessed parameters.

\section{CONCLUSIONS}

The decision-making process is inseparably connected with uncertainty and risk, the assessment of which and the possible minimization of the effects increasingly require the need to have quantitative information, preferably "synthetic" and relatively reliable. The decision-making process is perceived as the choice of the optimal solution and is more and more often identified with the practical adoption of mathematical methods. These methods enable global control of processes included within one integrated system, with an almost unlimited range of decision-making freedom (multi-variant design) and at the same time low costs of simulation runs.

An example of such a process is a multi-criteria assessment based on the development measure method, which, using variable normalization procedures and the Euclid distance formula, allows for determining the final aggregate value enabling selection of a variant that best meets the expectations of the decision maker. It should be noted that the final results may be subject to the judgment of the assessor (a person or persons), although the appropriate formal preparation and professional experience of the decision-maker(s) should minimize this risk.

\section{REFERENCES}

[1] W. Blaschke. "Prospects of coal in the world and Polish economy - a chance of Polish coal in the European Union", Polityka Energetyczna - Energy Policy, vol. 8 (Zeszyt specjalny), pp. 13-34, 2005.

[2] T. Borys. „Metody normowania cech statystycznych badaniach porównawczych", Przeglad Statystyczny", vol. 25 no. 2, pp. 227-239. 1978.

[3] L. Gawlik. "Costs connected with current production of coal according to regulations of the European Union and the costs of sold coal according to applied in Poland statistics of coal mining", Polityka Energetyczna, Zeszyt specjalny, vol. 7, Wyd. Instytut GSMiE PAN, Kraków, pp. 409-420, 2004.

[4] L. Gawlik. „Koszty produkcji węgla w procesach restrukturyzacji górnictwa węgla kamiennego", Gospodarka Surowcami Mineralnymi, vol. 22 no. 1 (Zeszyt specjalny), pp. 35-49, 2006.
[5] T. Grabiński. „Wielowariantowa analiza porównawcza w badaniach dynamiki zjawisk ekonomicznych", Zeszyty Naukowe Akademii Ekonomicznej w Krakowie, seria specjalna: Monografie, vol. 61. Kraków, 1984.

[6] International Accounting Standards/International Financial Reporting Standards (IAS/IFRS), http://www.ifrs.org/issued-standards/

[7] Jonek-Kowalska, M. Turek., „Koszty stałe i zmienne a efektywność produkcji w polskich kopalniach węgla kamiennego", Zeszyty Naukowe Politechniki Ślqaskiej. Seria: Organizacja i Zarzq̨dzanie no. 97 Nr kol. 1964, pp. 153-167, 2016.

[8] R. Magda. „Ocena wpływu ograniczenia stopnia wykorzystania zdolności produkcyjnej w ścianach wydobywczych na jednostkowy koszt własny", Przeglqd Górniczy, no 9, pp. 110-113, 2013.

[9] E.W. Maruszewska, M. Strojek-Filus, Z. Drábková. "Information about cost of goods produced and its usefulness for production engineers - a case of SME", Management Systems in Production Engineering, Vol. 25, Iss. 4, pp 267-272, 2017. DOI 10.1515/mspe-2017-0039.

[10] S. Mynarski (red.). „Badania przestrzenne rynku $i$ konsumpcji. Przewodnik metodyczny", PWN. Warszawa, 1992.

[11] E. Nowak. „Wkład ośrodka wrocławskiego w rozwój rachunku kosztów“, Prace Naukowe Uniwersytetu Ekonomicznego we Wrocławiu, vol. 389, pp. 275286, 2015 DOI: 10.15611/pn.2015.389.25

[12] W. Naworyta. „Analiza zmienności parametrów złożowych węgla brunatnego pod kątem sterowania jakością strumienia urobku - Variability analysis of lignite deposit parameters for output quality control", Gospodarka surowcami mineralnymi, vol. 24, no. 2/4, pp. 97-110, 2008.

[13] J. Pociecha. Metody statystyczne $w$ badaniach marketingowych, PWN, Warszawa, 1996.

[14] H. Przybyła, A. Chmiela. Projektowanie rozwiqzań techniczno-organizacyjnych stosowanych w wyrobiskach ścianowych, Wydawnictwo Politechniki Śląskiej. Skrypt 2063. Gliwice, 1997.

[15] H. Przybyła., Z. Korban. „Zastosowanie metod oceny wielokryterialnej w procesach wielowariantowego projektowania rozwiązań techniczno-organizacyjnych w zakładach górniczych" W: Moderni matematicke metody $v$ inzenyrstvi. Sbornik z 16 . seminare, Dolni Lomna, 4.6-6.6.2007. Vysoka Skola Banska Technicka Univerzita Ostrava. Katedra Matematiky a Deskriptivni Geometrie, Jednota Ceskych Matematiku a Fyziku. Pobocka Ostrava. Ostrava: VSB-Technicka Univerzita Ostrava, 2007, pp. 243-247.

[16] H. Przybyła, Z. Korban Z. „Wielokryterialna ocena rozwiązań T-T-O wzbogacona o analizę wrażliwości" Mechanizacja i Automatyzacja Górnictwa vol. 48 no 12, pp. 30-33, 2010. 
[17] S. Shafiee, E. Topal, "New approach for estimating total mining costs in surface coal mines", Mining Technology, vol. 121 no. 3, pp. 109-116, 2012. DOI: 10.1179/1743286312Y.0000000011.

[18] Ch. Shi, L. Guo, Y. Mei. "Analysis on Coal Price Forming Mechanism in China and Its Effect Factors", Management \& Engineering, vol. 18, pp. 29.33, 2015. DOI:10.5503/J.ME.2015.18.006.

[19] Sulik-Górecka, M. Strojek-Filus, E. Maruszewska. „IFRS valuation models vs. business entities' practice - a case of Polish publicly traded enterprises", European Financial Systems 2017. Proceedings of the $14^{\text {th }}$ International Scientific Conference. Part II, June 2627, 2017 Brno, Czech Republic, ed. J. Nesleha, T. Plihal, K. Urbanovsky, pp. 356-364, 2017.

[20] The Accounting Act as of 29th September 1994, the Journal of Laws No. 121, item 59; consolidated text dated 2016, the Journal of Laws, item 1047.

\section{dr inż. Aleksandra Sulik-Górecka}

University of Economics in Katowice

Faculty of Finance and Insurance

Department of Accounting

ul. 1 Maja 50, 40-287 Katowice, Poland,

e-mail: sulik_gorecka@ue.katowice.pl

\section{dr inż. Zygmunt Korban}

Silesian University of Technology

Faculty of Mining and Geology

Department of Safety Engineering

ul. Akademicka 2, 44-100 Gliwice, Poland

e-mail.: zygmunt.korban@polsl.pl 